\title{
Modification of recombinant human epidermal growth factor (rh-EGF) expression vector by site-directed mutagenesis for therapeutic protein production
}

\author{
Achmad Rodiansyah ${ }^{1,2^{*}}$, Riyona Desvy Pratiwi $^{2}$, Sabighoh Zanjabila $^{2}$, and Asrul Muhamad Fuad ${ }^{2}$ \\ ${ }^{1}$ Department of Biology State University of Malang, Semarang Street No. 5, Malang 65145, Indonesia \\ ${ }^{2}$ Research Center for Biotechnology, Indonesian Institute of Sciences, Jalan Raya Bogor KM.46, Cibinong 16911, Indonesia \\ *Corresponding author: a.rodiansyah@yahoo.com
}

SUBMITTED 14 December 2018 REVISED 16 April 2019 ACCEPTED 24 May 2019

\begin{abstract}
Recombinant human epidermal growth factor (rh-EGF) has high value in therapies for h-EGF deficiency-related diseases. The expression of the h-EGF gene was designed by using the pET21b(+) vector and Escherichia coli BL21(DE3) as the expression host. In a previous study, the sequence of a $6 x$ His tag without any restriction sites was fused to the h-EGF gene, yet it was not possible to obtain a purified and single rh-EGF by this approach. In this study, we modified the rh-EGF expression vector using site-directed mutagenesis (SDM) to remove the sequence of the $6 \mathrm{xH}$ is tag. The vector modification was carried out by inserting a stop codon and the EcoRI restriction site, along with deleting the $6 \times \mathrm{xHis}$ tag sequence. The results of PCR showed non-specific bands, while 2-step cycles PCR produced one non-specific band, and 3-step cycles PCR produced two non-specific bands. After purification of the PCR products, the SDM-recombinant plasmids treated for template plasmid-free product were transformed into $E$. coli DH $5 \alpha$. Even though the transformation efficiency was low, the planned gene mutations including the deletion of the $6 \times \mathrm{His}$ tag and insertion of the stop codon and EcoRI restriction site in plasmid pET21b(+) were successfully carried out. When using this modified vector in expression studies, rh-EGF of a similar size to that of the rh-EGF standard and approximately $1 \mathrm{kDa}$ smaller than the rh-EGF-6xHis of the previous study was obtained.
\end{abstract}

KEYWORDS Escherichia coli BL21(DE3); pET21b(+); recombinant human epidermal growth factor (rh-EGF); site-directed mutagenesis (SDM)

\section{Introduction}

Human epidermal growth factor (h-EGF) is a small protein to stimulate cell proliferation, differentiation, viability in various cell types such as epithelial cells, fibroblast cells, endothelial cells including tumor cells with complex regulatory mechanisms (Citri and Yarden 2006; Su et al. 2006; Xian 2007; Higashiyama et al. 2008; Zeng and Harris 2014). It is functional protein from derivate large precursor gene, this large precursor gene includes encoding membrane receptor, EGF-like repeats, and EGF or growth factor family (Bell et al. 1986; Zeng and Harris 2014). This protein can be detected in saliva, milk, intestinal fluid, and others (Fisher and Lakshmanan 1990; Xian 2007; Dvorak 2010). h-EGF protein is composed of 53 amino acids with three disulfide bonds with conserved be cysteines from C1 to C6 specified in glycine and arginine. This mature protein has molecule mass about 6.2 kDa (Savage et al. 1972, 1973; Zeng and Harris 2014). However, the rh-EGF used in this study has been added a methionine residue at the $\mathrm{N}$-terminal for intracellular expression in E. coli. In our sequence, disulfide bonds were formed by binding of C7-
C21; C14-C31, and C33-C43. In an in vivo study with pig and mice, it is showed that EGF can prevent and treat necrotizing enterocolitis and also be important in gastrointestinal repair (Nair et al. 2008). EGF suppresses fibrosis in mice liver induced by thioacetamide (TAA) associated with inhibiting hepatic stellate cells (Huang et al. 2012). EGF is important in remodeling the cytoskeleton for endocytosis and cell proliferation (Kharchenko et al. 2007). Growth factor family such as EGF contributed to wound healing in various tissues and their possibility play roles in therapy based on stem cells (Fu et al. 2002; Pikuła et al. 2015).

h-EGF has been synthesized by several recombinant protein techniques due to its importance in treatments from h-EGF lack-related diseases. The recombinant hEGF (rh-EGF) can be used for therapies in kidney destruction diseases such as glomerular disease (Flamant et al. 2012; Klein et al. 2016). Moreover, rh-EGF for patients with diabetic ulcers with level 1-4 showed significant repair of injury (Putri and Sriwidodo 2016) and rh-EGF spray also significantly useful for reduced mucositis oral induced by radiotherapy (Wu et al. 2009). 
In our previous study, rh-EGF was successfully inserted into the expression vector pET21b(+) and transformed to Escherichia coli DH5 $\alpha$ (Nurmalasari 2010). In the recombinant plasmid, the gene of h-EGF was fused with a gene of $6 x \mathrm{His}$ tag, but without any cleavage sites between them. Therefore, it is not possible to obtain single and purified h-EGF. In this study, the recombinant plasmid was modified by using PCR based-SDM to insert stop codon and delete the 6xHis tag sequences. Thus, it is expected that purified h-EGF could be obtained by other purification methods than affinity chromatography.

Site-directed mutagenesis (SDM) or site-specific mutagenesis is a technique in genetic engineering to introduce defined mutations into target DNA. The mutation is needed to improve the expression of a recombinant gene and in protein/enzymes studies (Xu et al. 2003; Antikainen and Martin 2005; Walquist and El-Gewely 2001). In genetic and protein engineering, the SDM is beneficial to generate DNA sequence with mutated codons including insertion or deletion by using polymerase chain reaction (PCR) (Edelheit et al. 2009; Walquist and El-Gewely 2001). PCR is a common amplification technique to obtain extremely high copies of target DNA (Bhatia and Dahiya 2015). PCR-based SDM method requires a pair of forward and reverse primers to amplify full-length plasmid containing a sequence of interest, 5'phosphorylation of the blunt-ended amplification product, degradation of PCR template with DpnI enzyme, ligation, and transformation (Rabhi et al. 2004; Walquist and El-Gewely 2001). The SDM technique has been applied in a number of studies, for instances to study interaction of type III secretion (T3S) components in model pathogenic bacterium of Yersinia (Francis et al. 2017), PCR-free CRISPR/Cas9 mutagenesis (She et al. 2018), and SDM in Arabidopsis with zinc finger nuclease (Osakabe et al. 2010).

According to the reported studies, PCR-based SDM offers a lot of advantages, such as almost $100 \%$ successful targeted mutation (Wan et al. 2012) and $>60 \%$ of subclones contain the desired mutation (Xu et al. 2003). Moreover, the PCR-based SDM is able to be designed with specific restriction sites which simplify the mutant screening and increase mutation reliability and fidelity (Edelheit et al. 2009; Zhang et al. 2009; Walquist and El-Gewely 2001).

\section{Materials and methods}

\subsection{Preparation of SDM-recombinant plasmid}

A template plasmid, namely pET21b(+)_egf.syn_6xHis tag was isolated from the recombinant subcloning host E. coli DH5 $\alpha \_$pET21b(+)_egf.syn_6xHis tag using the alkaline lysis method (Ausubel et al. 2002). The obtained recombinant plasmid was purified with Geneaid ${ }^{\mathrm{TM}}$ Gel/PCR DNA Frgments Extraction kit and then used as a template in PCR for SDM with KOD-Plus-Mutagenesis kit. Primers used for SDM are reverse primer: 5'-TTA TCA ACG AAG TTC CCA CCA TTT CAG ATC ACG ATA CTG GCA-3' and forward primer: 5'-GAA TTC
GAT CCG GCT GCT AAC AAA GCC CGA AAG3' (purchased from Integrated DNA Technologies-IDT ${ }^{\circledR}$, Singapore). The PCR mixture was prepared in accordance with the standard protocol for the KOD-Plus-Mutagenesis kit and KOD-Plus-Neo kit. Subsequently, the 2-step cycles PCR was performed as follows: pre-denaturation: 2 min at $94^{\circ} \mathrm{C}$, denaturation: $10 \mathrm{~s}$ at $98^{\circ} \mathrm{C}$, annealing: 30s at $68^{\circ} \mathrm{C}$, extension: $2 \mathrm{~min} 45 \mathrm{~s}$ at $68^{\circ} \mathrm{C}$, hold at $4^{\circ} \mathrm{C}$, and for annealing temperature screening use 3-step cycles PCR was performed as follows: pre-denaturation: $2 \mathrm{~min}$ at $94^{\circ} \mathrm{C}$, denaturation: $10 \mathrm{~s}$ at $98^{\circ} \mathrm{C}$, annealing: $30 \mathrm{~s}$ at [56.364.2 $]^{\circ} \mathrm{C}$, extension: $2 \mathrm{~min} 45 \mathrm{~s}$ at $68^{\circ} \mathrm{C}$, hold at $4^{\circ} \mathrm{C}$. Afterward, the obtained PCR product was treated using DpnI enzyme mixture to digest the template plasmid which contaminated the PCR product at $37^{\circ} \mathrm{C} 1 \mathrm{~h}$. The template plasmid free-PCR product was purified with a Geneaid ${ }^{\mathrm{TM}}$ Gel/PCR DNA Fragments Extraction kit. The target template plasmid free-PCR product was then ligated with a ligation enzyme in a KOD-Plus-Mutagenesis kit. The product of the ligation was subsequently named as the SDMrecombinant plasmid.

\subsection{Transformation of SDM-recombinant plasmid to $\mathrm{E}$. coli DH5 $\alpha$ and transformants stability test}

Transformation of product the SDM-recombinant plasmid using calcium chloride $\left(\mathrm{CaCl}_{2}\right)$ heat-shock treatment (Ausubel et al. 2002). The competent cells were prepared by harvesting subculture of E. coli DH5 $\alpha$ at OD 0.25-0.3 and centrifugation at $6000 \mathrm{rpm}, 10 \mathrm{~min}$ at $4^{\circ} \mathrm{C}$. The pellets were resuspended with $\mathrm{CaCl}_{2}$ then incubated in ice water for $30 \mathrm{~min}$. The $\mathrm{CaCl}_{2}$ treated pellet was centrifuged again at $6000 \mathrm{rpm}, 10 \mathrm{~min}$ at $4{ }^{\circ} \mathrm{C}$ and resuspended with $\mathrm{CaCl}_{2}$ $+15 \%$ glycerol. The competent cells can be stored in the freezer $-80^{\circ} \mathrm{C}$. Prior to transformation, $7.5 \mu \mathrm{L}$ of SDMrecombinant plasmid was added to $50 \mu \mathrm{L}$ competent cells and incubated on ice for $20 \mathrm{~min}$. Heat-shock treatment was conducted by placing the transformation mixture in $42^{\circ} \mathrm{C}$ water for $30 \mathrm{~s}$ then keeping it in ice water for $5 \mathrm{~min}$. After heat-shock treatment, $450 \mu \mathrm{L} \mathrm{LB}$ medium was added to the transformation mixture and incubated at $37^{\circ} \mathrm{C}, 200$ rpm, $1 \mathrm{~h}$. A number $100 \mu \mathrm{L}$ and $150 \mu \mathrm{L}$ of the transformation mixture was spread on LB agar plate with ampicillin (AMP) $10 \mu \mathrm{g} / \mathrm{mL}$ and incubated at $37^{\circ} \mathrm{C}$ overnight. The transformants stability test was performed by regeneration the single colonies of the transformants on LB agar + AMP $10 \mu \mathrm{g} / \mathrm{mL}$ plate.

\subsection{Transformants verification by $P C R$, digestion by en- zyme restriction, and DNA sequencing}

Verification of the transformants was generated with three methods: PCR, EcoRI restriction enzyme digestion and DNA sequencing. First, single colonies obtained from the transformations (or named as transformants) were verified by PCR, using primers of targeted gene (egf.syn) (IDT ${ }^{\circledR}$, Singapore) with set as follows: pre-denaturation: $5 \mathrm{~min}$ at $95^{\circ} \mathrm{C}$, denaturation: $30 \mathrm{~s}$ at $95^{\circ} \mathrm{C}$, annealing: $30 \mathrm{~s}$ at $55^{\circ} \mathrm{C}$, extension: $30 \mathrm{~s}$ at $72^{\circ} \mathrm{C}$, final extension $60 \mathrm{~s}$ at $72^{\circ} \mathrm{C}$ and hold at $4^{\circ} \mathrm{C}$. Second, the SDM-recombinant plasmid was 
also checked with EcoRI restriction enzyme which is specific for the SDM-recombinant plasmid. The restriction mixture reaction contained buffer orange $1 \mu \mathrm{L}$ (Thermo Scientific, Lithuania), sample (SDM-recombinant plasmid) $1 \mu \mathrm{L}$, EcoRI enzyme (Thermo Scientific, Lithuania) 5 units $1 \mu \mathrm{L}$, and $\mathrm{dH}_{2} \mathrm{O} 3 \mu \mathrm{L}$. The mixture was incubated at $37^{\circ} \mathrm{C}$ overnight and checked on agarose gel electrophoresis 0.7 percent. Final verification was DNA sequencing of the SDM-recombinant plasmid with primer sequencing $\mathrm{T} 7$ promoter and $\mathrm{T} 7$ terminator.

\subsection{Expression of SDM modified rh-EFG in E. coli BL21(DE3)}

Purified SDM-recombinant plasmid from E. coli DH5 $\alpha$ was transformed to E. coli BL21(DE3) expression host. The transformants were then pre-cultured in $1 \mathrm{~mL} \mathrm{LB}$ medium with AMP $10 \mu \mathrm{g} / \mathrm{mL}$, incubated at $37^{\circ} \mathrm{C} ; 180$ rpm overnight. On the following day, $0.5 \mathrm{~mL}$ of preculture was added to $5 \mathrm{~mL}$ LB medium and incubated at $37^{\circ} \mathrm{C}$; $180 \mathrm{rpm}$; approximately for $2 \mathrm{~h}$ or until reaching OD 0.6-0.8. Subsequently, the culture was added with isopropyl $\beta$-D-1-thiogalactopyranoside or IPTG (Thermo Scientific, Lithuania) (final concentration $0.1 \mathrm{mM}$ ) and incubated for $6 \mathrm{~h}$ at $37^{\circ} \mathrm{C}$; $180 \mathrm{rpm}$. After IPTG induction, the cells (pellet) were collected by centrifugation at $8,000 \mathrm{rpm} ; 5 \mathrm{~min} ; 4^{\circ} \mathrm{C}$. The pellet was then solubilized with solubilization buffer (8 M urea; $50 \mathrm{mM}$ glycine; 80 $\mathrm{mM} \beta$-mercaptoethanol) and incubated at a cold temperature $\left(8-10^{\circ} \mathrm{C}\right)$ for $72 \mathrm{~h}$. The solubilized protein was obtained by centrifugation at 12,000 rpm; $15 \mathrm{~min}$, and then analyzed with tricine SDS PAGE (acrylamide 15\%; 70 volts), also verified with western blotting against monoclonal antibody EGF (Santa Cruz, USA). The SDM modified rh-EGF was compared with rh-EGF standard (Sigma) and rh-EGF with 6xHis tag.

\section{Results and discussion}

\subsection{Preparation of SDM-recombinant plasmid}

The result of plasmid purification from gel extraction contained two bands (Figure 1). Based on the theory, plasmids are separated on gel electrophoresis according to its topologies (De Mattos et al. 2004; Cebrián et al. 2014), which are supercoiled (SC), open-circle (OC) or linear (L)

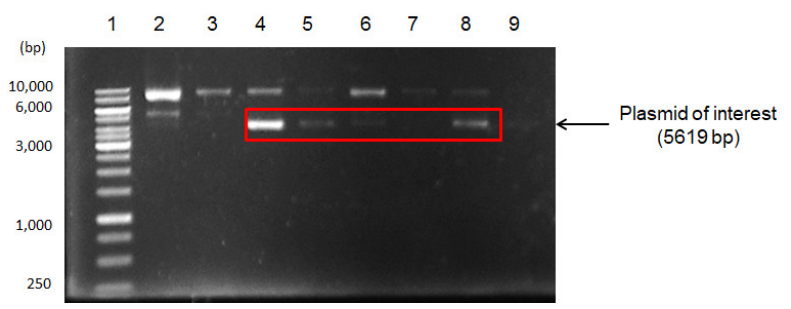

FIGURE 1 Electroforegram of plasmid purification. $1=$ Marker (1 $\mathrm{kb}), 2=3 \mathrm{~B}_{1} 1^{\text {st }}$ elute, $3=3 \mathrm{~B}_{1} 2^{\text {nd }}$ elute, $4=3 \mathrm{~B}_{2} 1^{\text {st }}$ elute, $5=3 \mathrm{~B}_{2}$ $2^{\text {nd }}$ elute, $6=3 \mathrm{D}_{1} 1^{\text {st }}$ elute, $7=3 \mathrm{D}_{2} 2^{\text {nd }}$ elute, $8=3 \mathrm{D}_{2} 1^{\text {st }}$ elute, $9=3 D_{2} 2^{\text {st }}$ elute. Sample $3 B_{2} 1^{\text {st }}$ elute is used as a template PCR for SDM. Code of samples " $B$ " and " $D$ " was a single colony from the previous study.
(Balagurumoorthy et al. 2008; Carbone et al. 2012). The plasmid yield was varied significantly depending on the elution. The first elution produced a thicker band than second elution did. The purified plasmid in line 4 was used as a PCR template because it showed the thickest band or in other word had the highest concentration among the other purified plasmids.

The result of PCR products can be seen in Figure 2. Electroforegram of amplicon in $0.7 \%$ electrophoresis gel showed that two non-specific bands were found after 3step cycles PCR (Figure 2a) and one non-specific band was from 2-step cycles PCR (Figure 2b).

Wan et al. (2012) and Edelheit et al. (2009) mentioned that several factors in primer design might cause nonspecific bands such as complicated mutation, high content of G-C, complex secondary structure, tandem and inverted sequence, and insertion of long primers. In our study, the

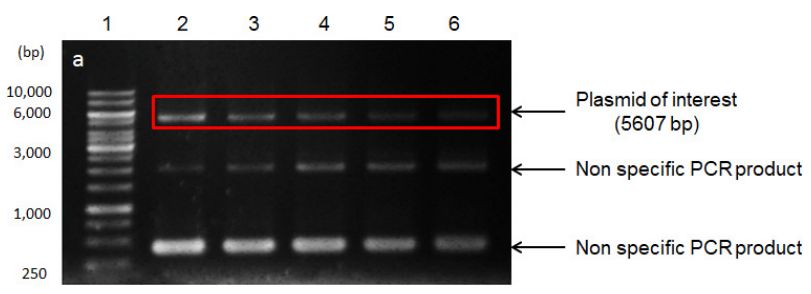

(a)

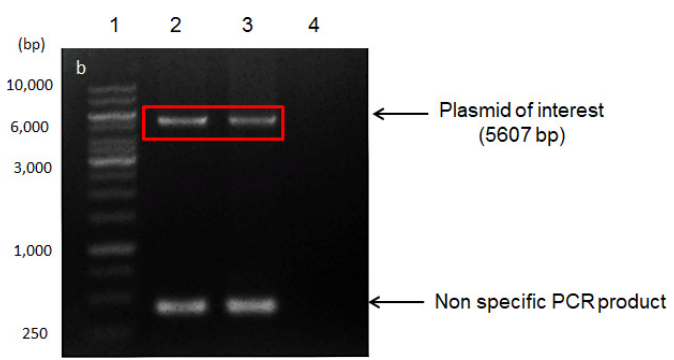

(b)

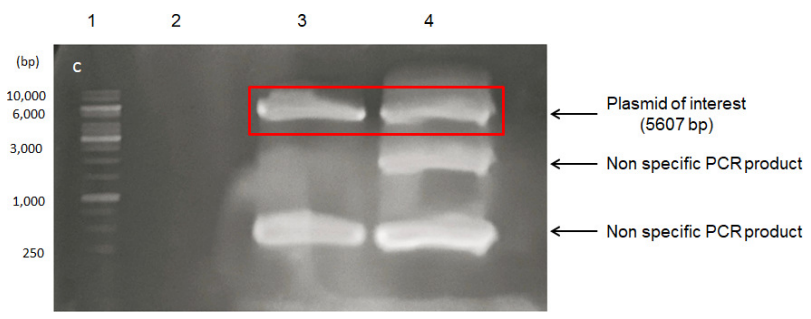

(c)

FIGURE 2 Electroforegram of amplicon for SDM with various annealing temperature, a) Electroforegram of 3-step cycles PCR. $1=$ Marker $(1 \mathrm{~kb}), 2=64.2^{\circ} \mathrm{C}, 3=62.2^{\circ} \mathrm{C}, 4=60.2^{\circ} \mathrm{C}, 5=58.1^{\circ} \mathrm{C}, 6=$ $56.3^{\circ} \mathrm{C}$. PCR product for SDM showed 2 nonspecific products, b) Electroforegram of 2-step cycles PCR $\left(\mathrm{Tm}=68^{\circ} \mathrm{C}\right) .1=$ Marker $(1$ $\mathrm{kb}), 2$ = once dilution template, $3=$ without dilution template, 4 $=$ control $\left(\mathrm{dH}_{2} \mathrm{O}\right)$. PCR product for SDM showed 1 band nonspecific product. c) Purification of template free-PCR product after treated with Dpnl enzyme, 1 = Marker. 2 = template plasmid freePCR product from KOD-Plus-Mutagenesis kit, $3=$ template plasmid free-PCR product from KOD-Plus-Neo kit 2-step cycles PCR, $4=$ template plasmid free-PCR product from KOD-Plus-Neo kit 3step cycles PCR. 


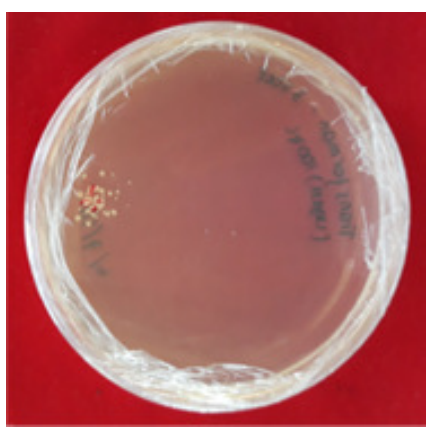

(a)

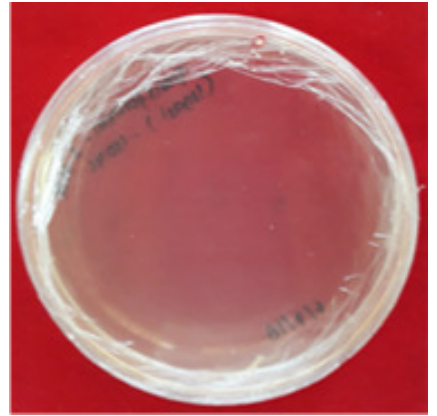

(b)

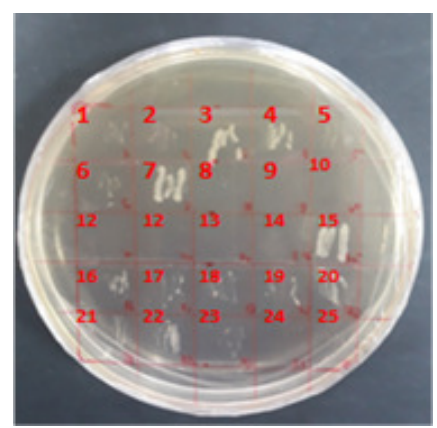

(c)

FIGURE 3 a) Plate $100 \mu \mathrm{L}$ of transformation culture, b) Plate $150 \mu \mathrm{L}$ of transformation culture, c) Replica plating of transformant single colonies from plate $a(8-25)$ and transformation culture plate $b(1-7)$.

plasmid template has a size of 5,619 bp, thus the possibility that several bases are compatible with the primers is high. The primers could bound to a region that was not in the target primer-template binding. Non-specific bands can be seen in Figure 2a and 2b. Other reasons for non-specific bands are the PCR condition. We used either 2-step cycles PCR or 3-step cycles PCR in our experiment. A 2-step PCR cycling includes denaturation and annealing/extension, while in 3-step PCR extension step after annealing is added (Lorenz 2012). Too low denaturing temperature (Roux 1995) and not optimal annealing temperature (Vestheim and Jarman 2008; Kalendar et al. 2017) might also cause non-specific bands. Primers melting temperature (Tm primer) is the most important factor in the success of PCR. In addition, optimized cycling condition and reagent concentration also contribute to producing amplicons with the expected size. Changing a parameter can influence other parameters, hence the production of the amplicon is affected as well (Lorenz 2012). The result showed the best annealing temperature was at $68^{\circ} \mathrm{C}$ in 2 step cycles PCR with an indicator such as forming one nonspecific band produced, while in annealing temperature below $68^{\circ} \mathrm{C}$ in 3 -step cycles PCR $\left(64.2-54.3^{\circ} \mathrm{C}\right)$ program were formed two non-specific PCR products. The optimum PCR reactions ensure the amplification of the DNA target and increase the quality of amplicons target (Joko et al. 2011). Therefore, differences in temperature used in annealing with 3-step cycles and 2-step cycles PCR program produce a number of different bands.

All PCR products either from 3-step cycles PCR or 2-step cycles PCR with KOD-Plus-Neo and KOD-PlusMutagenesis were treated with $D p n I$ enzyme and purified on gel electrophoresis (Figure 2c). DpnI enzyme is specific to digest PCR templates, particularly at the methylated adenine base of GATC sequence in parental strand (Johnston et al. 2013), but not in the PCR product (Walquist and El-Gewely 2001). DNA methylation is often described as a parental epigenetic sign and can be inherited through cell division, this mechanism is caused by DNA binding proteins that bind DNA (Jones 2012; Moore et al. 2013) so this site is found repeatedly in parental strand (Sánchez-Romero et al. 2015). The repetition of this site makes the template degradation more effective so that pure PCR products are easy to be obtained. The template plasmid free-PCR product was then purified and ligated with ligation enzyme. Ligation enzyme catalyzes the formation phosphodiester bonds between 3' hydroxyls $(\mathrm{OH})$ and 5' phosphates $\left(\mathrm{PO}_{4}\right)$ in nucleic acid residues (Lohman et al. 2013) from this formation the circular plasmid can be formed.

\subsection{Transformation of SDM-recombinant plasmid to $\mathrm{E}$. coli DH5 $\alpha$ and transformants verification by PCR}

Successful transformation is characterized by the growth of colonies on selective medium (LB + Amp $10 \mu \mathrm{g} / \mathrm{mL}$ ). The successful transformation was only obtained from the SDM-recombinant plasmid which was ligated from 3-step cycles PCR product (Figure 3). On the plate with $100 \mu \mathrm{L}$ transformation culture (Figure 3a), 16 single colonies were found while on the other plates, seven single colonies grew (Figure 3b).

The successive rate of this transformation method is determined by $\mathrm{Ca}^{2+}$ and heat shock temperatures (Rahimzadeh et al. 2016). A pulse of $30 \mathrm{~s}$ duration at $42^{\circ} \mathrm{C}$ heat shock temperature followed by a $10 \mathrm{~min}$ ice incubation exhibited maximum efficiency, with a transformation efficiency $3 \times 10^{8} \mathrm{cfu} / \mu \mathrm{g}$ in DH5 $\alpha$ (Singh et al. 2010). Transformation efficiency in this study is low, so it is necessary to repeat the transformation procedure. Few or no transformants present might be caused by cells which are

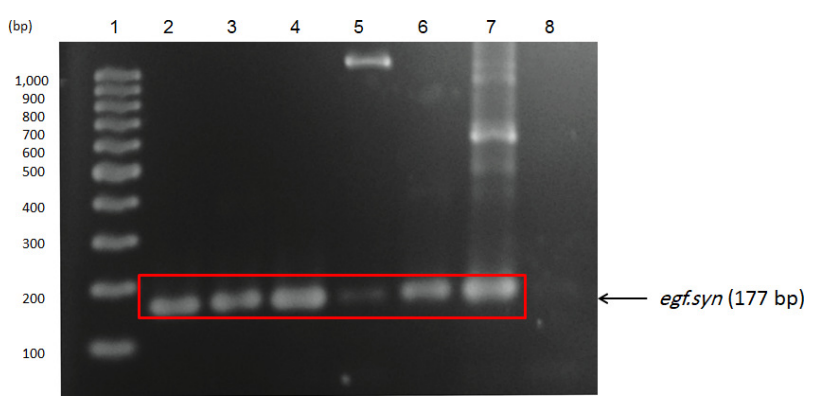

FIGURE 4 Verification SDM-recombinant plasmid with target gene (egf.syn). 1 = Marker (100 bp), 2 = colony 3, 3 = colony 7, 4 = colony $15,5=$ colony $22,6=$ positive control (1st elute from miniprep), $7=$ positive control (ligation plasmid), $8=$ negative control $\left(\mathrm{dH}_{2} \mathrm{O}\right)$. 


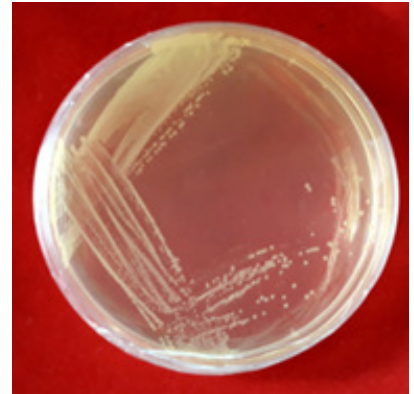

(a)

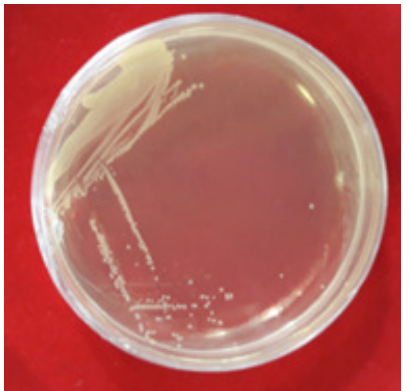

(b)

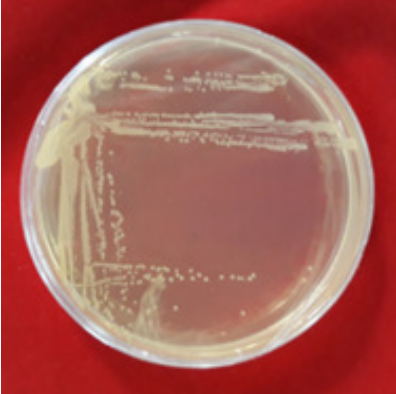

(c)

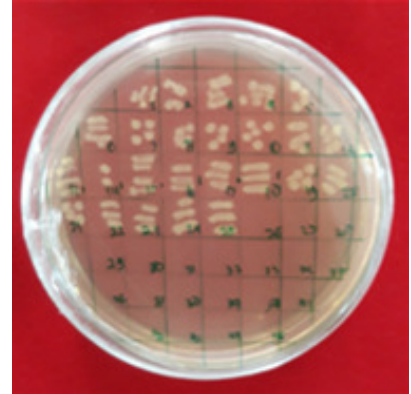

(d)

FIGURE 5 a) streak colony 3, b) streak colony 7, c) streak colony 15, d) replica plating for streak colony 3 (1-10), streak colony 7 (11-20) and streak colony 15 (21-25).

not competent and incorrect heat-shock protocol. Most cases of transformation failure due to heat shock temperature is inaccurate (Chang et al. 2017). The temperature is important because the heat-shock step is a facilitator for competent cells to intake DNA or plasmid (Das and Dash 2015; Chang et al. 2017). This problem can be fixed by preparing a new batch of competent cells by improvement in heat-shock and incubation temperatures and duration and use a water bath for accuracy temperature in heat-shock step.

Subsequently, each colony was regenerated in a replica plating. Replica plating is the technique to inoculate each colony/clone into multiple plates that used to select specific hybridization, reduce the risk of environmental microbial contamination and cross-contamination between colonies (Carson et al. 2019). The best growth was found in replica colonies number 3 and 7 from a plate with $100 \mu \mathrm{L}$ transformation culture and replica colonies number 15 and 22 from a plate with $150 \mu \mathrm{L}$ transformation culture (Figure 3a). The single colonies number 3, 7 and 15, 22 from replica plating were used for PCR colonies for screening egf.syn sequence. Visualization of PCR colonies using target gene (egf.syn) primer on gel electrophoresis $0.7 \%$. The result PCR colony showed that replica colonies number 3, 7 and 15 positively had egf.syn sequence, while the colony 22 showed a thin band of egf.syn and a contaminant band. Positive control showed band of egf.syn, but they had non-specific PCR product and also no band was found from negative control (Figure

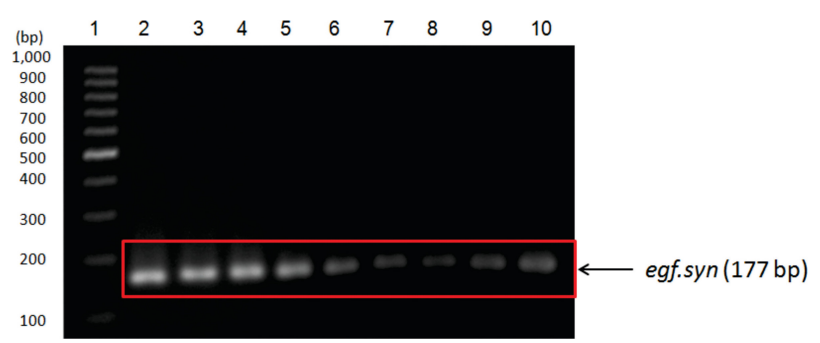

FIGURE 6 Verification SDM-recombinant plasmid target gene (egf.syn), 1 = Marker (100 bp), 2 = colony 3.1, 3 = colony 3.2, $4=$ colony $3.3,5=$ colony $7.1,6=$ colony $7.2,7=$ colony $7.3,8=$ colony $15.1,9=$ colony $15.2,10=$ colony 15.3 .
4). From this result, colonies number 3, 7 and 15 were streak again to regenerated on a new plate.

Figure 5 shows the results of colony streak regeneration from colonies number 3, 7 and 15, whereas colony number 22 was not regenerated because suspected to be a contaminant product. From the colony number 3, 7 and 15, a number of re-single colonies were obtained, i.e 55 colonies (Figure 5a), 26 colonies (Figure 5b) and 15 colonies (Figure 5c), respectively. Subsequently, from the regenerated single colony, 10 of 55; 10 of 26 and 5 of 15 colonies were randomly reselected to be replicated on a new plate (Figure 5d). Three sub-single colonies from each colony on the plate in Figure 5d have isolated the plasmid and then used in SDM verification with PCR colonies to screening egf.syn sequence.

Visualization of the PCR sub-colonies using primer target gene (egf.syn) for second replica cultures from streak colonies 3, 7 and 15 are shown on Figure 6. All samples were found to have a egf.syn sequence. Based on these results, sub-colonies 3.2, 7.2 and 15.2 were selected to be checked with the EcoRI restriction enzyme.

\subsection{Transformants verification by digestion with en- zyme restriction, and DNA sequencing.}

\subsubsection{Digestion by EcoRI restriction enzyme}

The EcoRI restriction enzyme was used to check specific sequence (G/AATTC) in SDM-recombinant plasmid

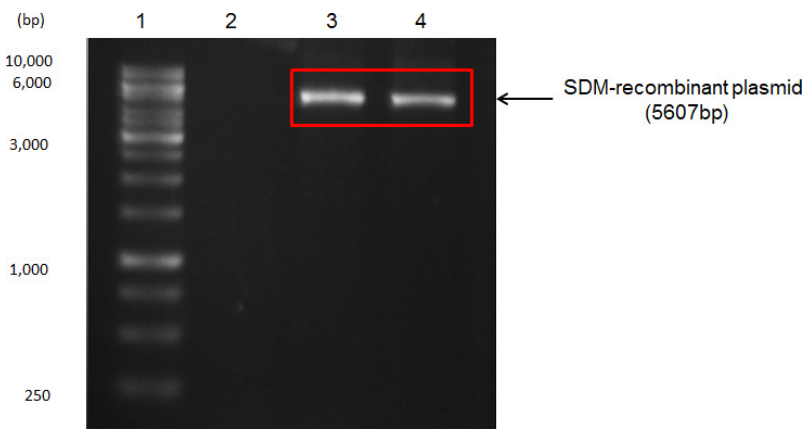

FIGURE 7 Verification SDM-recombinant plasmid with EcoRI restriction, 1 = subclone $3.2,2$ = subclone $7.2,3$ = subclone $15.2,4$ $=\operatorname{marker} 1 \mathrm{~kb}$. 


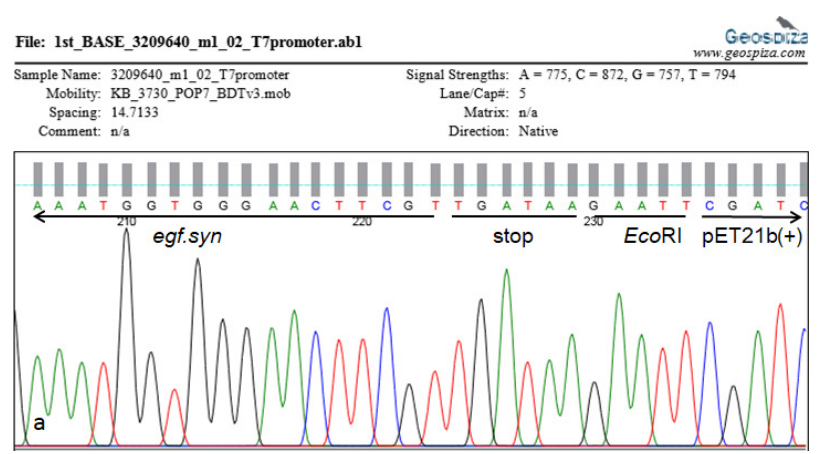

(a)

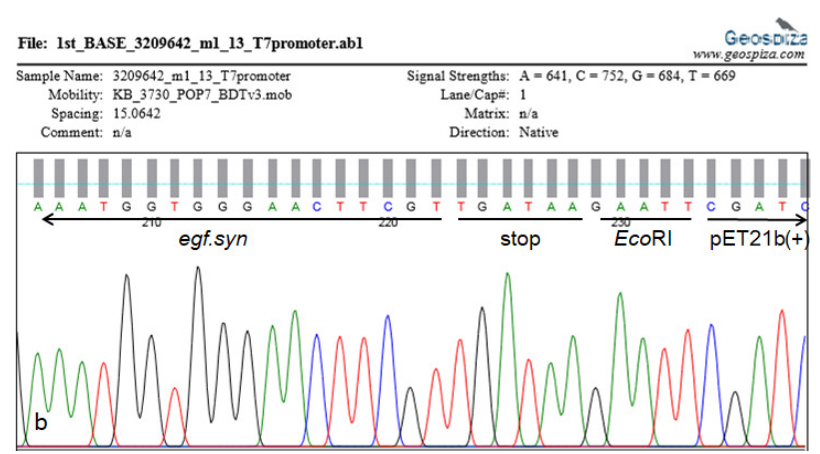

(b)

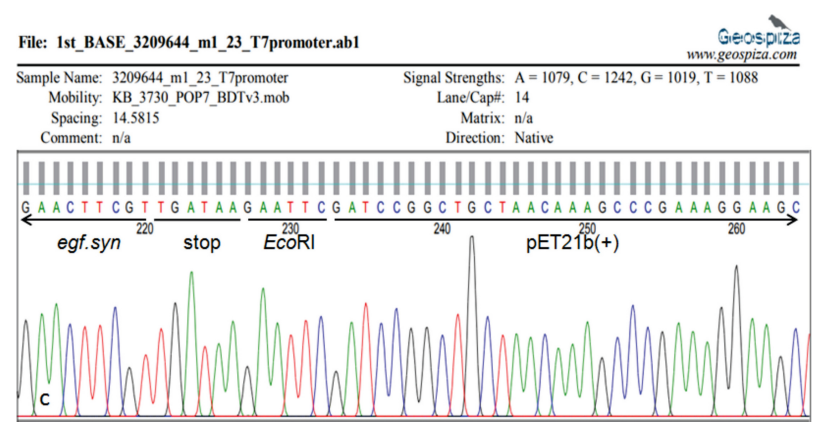

(c)

FIGURE 8 Final verification SDM-recombinant plasmid with DNA sequencing. a) DNA sequencing result of sub-colonies 3.2, b) DNA sequencing result of sub-colonies 7.2, c) DNA sequencing result of sub-colonies 15.2 .

(Shivanand and Noopur 2010). The restriction EcoRI sequence has been encoded on the SDM forward primer. Design restriction site in mutagenesis primers to ensure efficient mutant screening (Zhang et al. 2009). Visualization of successful EcoRI restriction can be seen on electrophoresis gel $0.7 \%$ (Figure 7). All samples showed similar bands with the same band location with an estimated size of 5,607 bp. Line number 3 did not show a band because no template added in the mixture for EcoRI restriction treatment.

\subsubsection{DNA sequencing}

Three transformants (sub-colonies number 3.2, 7.2 and 15.2) were confirmed by DNA sequencing using 1st BASE (Malaysia). The universal primers used for DNA sequencing were the T7 promoter primer and T7 termina-

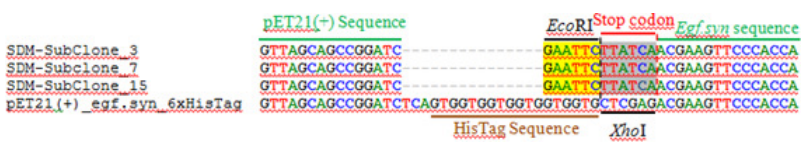

FIGURE 9 Alignment DNA sequencing of SDM-recombinant plasmid with control sequence (recombinant plasmid before SDM).

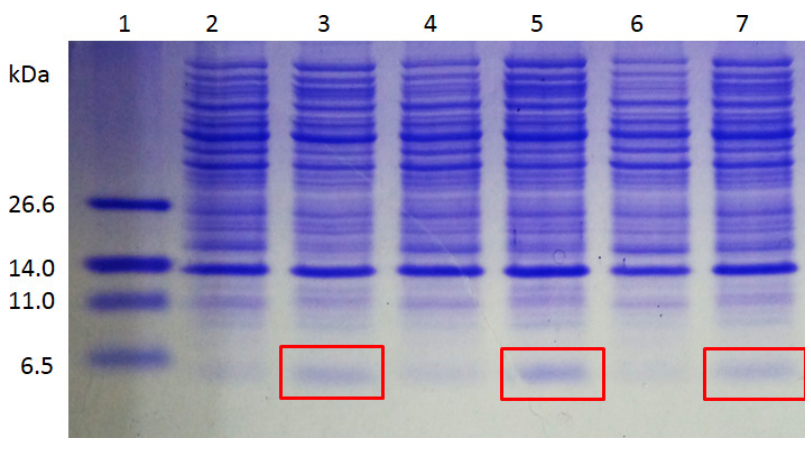

FIGURE 10 SDS PAGE profile of solubilized cells pellet from rh-EGF expression in E. coli BL21(DE3). Lane 2; 4; 6: uninduced condition; lane $3 ; 5 ; 7$ : IPTG induced $(0.1$ mM). Lane 2; 3: BL21(DE3)_pET21b(+)_rh-EGF_no.3.2; Lane 4; 5: $\quad$ BL21(DE3)_pET21b(+)_rh-EGF_no.7.2; 6;7: BL21(DE3)_pET21b(+)_rh-EGF_no.15.2. The rh-EGF is clearly expressed with IPTG induction, but slighly appear in uninduced condition. Lane 1: low protein marker.

tor primer. All of the samples had the expected mutations, conserved reading frame and no mutations were observed in the target gene (egf.syn). In addition, they were successfully added with two stop codons and EcoRI restriction sites also succeeded in deleting 6xHis tag sequences (Figures $8 \mathrm{a}, 8 \mathrm{~b}$ and $8 \mathrm{c}$ ). Sequence alignment with software clustalX and Bioedit of sequence from DNA sequencing results shows more clearly the deletion $6 x$ His tag sequence and insertion EcoRI restriction sequence and stop codons (Figure 9).

\subsection{Expression of SDM modified rh-EFG in E. coli BL21(DE3)}

The SDM-modified rh-EGF vector has been used to express the rh-EGF without 6xHis tag. The rh-EGF was expressed by IPTG induction at $0.1 \mathrm{mM}$ and found at less than $6.5 \mathrm{kDa}$ in size (Figure 10). Some samples from uninduced treatment also shows rh-EGF expression, but not significant. It was expressed in uninduced condition due to leaky of the expression system having a strong promoter such as T7 promoter Tegel et al. (2011).

In Figure 11, it was proven that after removing the $6 x$ His tag, the rh-EGF was obtained at similar size with the standard, while the rh-EGF_6xHis tag has bigger size, approximately $1 \mathrm{kDa}$, the theoretical size of $6 x \mathrm{His}$ tag (Zhu and Qian 2012). In regard to the removing 6xHis tag, affinity chromatography, particularly Ni-NTA chromatography, is not suitable to purify the rh-EGF from other $E$. coli endogenous proteins (Hochuli et al. 1988). Other purification methods, like size exclusion and/or ion exchange chromatography, might be applied (Suortti 1997). 


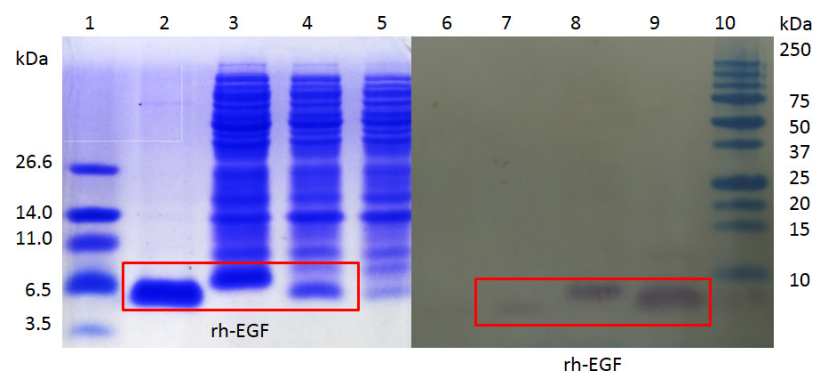

FIGURE 11 SDS PAGE (1-5) and western blot (6-10) profile of rhEGF after SDM modification compared with that of with 6xHis tag and rh-EGF standard. Lane $2 \&$ 9: rh-EGF standard; Lane $3 \& 8$ : rh-EGF_6xHis tag; Lane $4 \&$ 7: IPTG induced rh-EGF; Lane $5 \& 6$ : uninduced sample. The rh-EGF standard has a similar size with rhEGF after SDM modification which is less than $6.5 \mathrm{kDa}$. The rhEGF_6xHis tag has app. $1 \mathrm{kDa}$ size bigger than the rh-EGF.

\section{Conclusions}

The rh-EGF vector has been successfully modified by SDM. EcoRI restriction site sequence, stop codons had been inserted, and 6xHis tag had been successfully deleted from plasmid expression vector pET21b(+) recombinant. Therefore, the modified vector expressed rh-EGF without $6 x$ His tag and had a similar size with rh-EGF standard. In this study, it was proven that the PCR based SDM was an effective, precise, simple, and low-cost technique to improve or modify a recombinant plasmid.

\section{Acknowledgments}

This study was financially supported by Indonesia Toray Science Foundation 2017.

\section{Authors' contributions}

AMF and RDP designed the study; AR and SZ carried out the laboratory work; AR and RDP analyzed the data and wrote the manuscript. All authors read and approved the final version of the manuscript.

\section{Competing interests}

The authors declare that no competing interests of this work.

\section{References}

Antikainen NM, Martin SF. 2005. Altering protein specificity: techniques and applications. Bioorg Med Chem. 13(8):2701-2716. doi:10.1016/j.bmc.2005.01. 059.

Ausubel FM, Brent R, Kingston RE, Moore DD, Seidman JG, Smith JA, Struhl K. 2002. Short protocols in molecular biology. 5th ed. New York: John Wiley \& Sons.

Balagurumoorthy P, Adelstein SJ, Kassis AI. 2008. Method to eliminate linear DNA from mixture containing nicked circular, supercoiled, and linear plasmid dna. Anal Biochem. 381(1):172-174. doi:10.1016/ j.ab.2008.06.037.
Bell GI, Fong NM, Stempien MM, Wormsted MA, Caput D, Ku L, Urdea MS, Rall LB, Sanchez-Pescador R. 1986. Human epidermal growth factor precursor: cDNA sequence, expression in vitro and gene organization. Nucleic Acids Res. 14(21):8427-8446. doi: 10.1093/nar/14.21.8427.

Bhatia S, Dahiya R. 2015. Concepts and techniques of plant tissue culture science. In: Bhatia S, Sharma K, Dahiya R, Bera T, editors. Modern Applications of Plant Biotechnology in Pharmaceutical Sciences. Cambridge: Academic Press. p. 121-156.

Carbone A, Fioretti FM, Fucci L, Ausió J, Piscopo M. 2012. High efficiency method to obtain supercoiled DNA with a commercial plasmid purification kit. Acta Biochim Pol. 59(2):275-278. doi:10.18388/abp. 2012_2151.

Carson S, Miller HB, Srougi MC, Witherow DS. 2019. Molecular biology techniques: a classroom laboratory manual. London: Academic Press.

Cebrián J, Kadomatsu-Hermosa MJ, Castán A, Martínez V, Parra C, Fernández-Nestosa MJ, Schaerer C, Martínez-Robles ML, Hernández P, Krimer DB. 2014. Electrophoretic mobility of supercoiled, catenated and knotted DNA molecules. Nucleic Acids Res. 43(4):e24-e24. doi:10.1093/nar/gku1255.

Chang AY, Chau VW, Landas JA, Pang Y. 2017. Preparation of calcium competent Escherichia coli and heatshock transformation. JEMI Methods. 1:22-25.

Citri A, Yarden Y. 2006. EGF-ERBB signalling: towards the systems level. Nat Rev Mol Cell Biol. 7(7):505516. doi:10.1038/nrm1962.

Das S, Dash HR. 2015. Cloning and transformation in microbial biotechnology. In: Microbial biotechnology - a laboratory manual for bacterial systems. New Delhi: Springer. p. 35-72. doi:10.1007/978-81-322-2095-4_ 2.

De Mattos JCP, Dantas FJS, Caldeira-de-Araújo A, Moraes MO. 2004. Agarose gel electrophoresis system in the classroom: detection of DNA strand breaks through the alteration of plasmid topology. Biochem Mol Biol Educ. 32(4):254-257. doi:10.1002/bmb. 2004.494032040382.

Dvorak B. 2010. Milk epidermal growth factor and gut protection. J Pediatr. 156(2 Suppl):S31-S35. doi:10. 1016/j.jpeds.2009.11.018.

Edelheit O, Hanukoglu A, Hanukoglu I. 2009. Simple and efficient site-directed mutagenesis using two singleprimer reactions in parallel to generate mutants for protein structure-function studies. BMC Biotechnol. 9(1):61. doi:10.1186/1472-6750-9-61.

Fisher DA, Lakshmanan J. 1990. Metabolism and effects of epidermal growth factor and related growth factors in mammals. Endocr Rev. 11(3):418-442. doi: 10.1210/edrv-11-3-418.

Flamant M, Bollée G, Hénique C, Tharaux PL. 2012. Epidermal growth factor: a new therapeutic target in glomerular disease. Nephrol Dial Transplant. 27(4):1297-1304. doi:10.1093/ndt/gfs030. 
Francis MS, Amer AA, Milton DL, Costa TR. 2017. Site-directed mutagenesis and its application in studying the interactions of T3S components. In: Nilles ML, Condry DLJ, editors. Type 3 secretion systems. New York: Springer. p. 11-31. doi:10.1007/ 978-1-4939-6649-3_2.

Fu XB, Sun XQ, Sun TZ, Dong YH, Gu XM, Chen W, Sheng ZY. 2002. Epidermal growth factor stimulates tissue repair in skin through skin stem cell activation. Zhongguo Xiu Fu Chong Jian Wai Ke Za Zhi. 16(1):31-35.

Higashiyama S, Iwabuki H, Morimoto C, Hieda M, Inoue H, Matsushita N. 2008. Membrane-anchored growth factors, the epidermal growth factor family: beyond receptor ligands. Cancer Sci. 99(2):214-220. doi:10. 1111/j.1349-7006.2007.00676.x.

Hochuli E, Bannwarth W, Döbeli H, Gentz R, Stüber D. 1988. Genetic approach to facilitate purification of recombinant proteins with a novel metal chelate adsorbent. Nat Biotechnol. 6(11):1321-1325. doi:10.1038/ nbt1188-1321.

Huang G, Besner GE, Brigstock DR. 2012. Heparinbinding epidermal growth factor-like growth factor suppresses experimental liver fibrosis in mice. Lab Investig. 92(5):703-712. doi:10.1038/labinvest.2012.3.

Johnston C, Polard P, Claverys JP. 2013. The DpnI/DpnII pneumococcal system, defense against foreign attack without compromising genetic exchange. Mob Genet Elements. 3(4):e25582-1-e25582-8. doi:10.4161/ mge.25582.

Joko T, Kusumandari N, Hartono S. 2011. Optimasi metode PCR untuk deteksi Pectobacterium carotovorum, penyebab penyakit busuk lunak anggrek. [Optimization of the PCR method for detection of Pectobacterium carotovorum, the cause of orchid soft rot]. J Perlindungan Tanaman Indones. 17(2):54-59. doi: doi.org/10.22146/jpti.9813.

Jones PA. 2012. Functions of DNA methylation: islands, start sites, gene bodies and beyond. Nat Rev Genet. 13(7):484-492. doi:10.1038/nrg3230.

Kalendar R, Tselykh TV, Khassenov B, Ramanculov EM. 2017. Introduction on using the FastPCR software and the related java web tools for PCR and oligonucleotide assembly and analysis in PCR. Methods Mol Biol. 1620:33-64. doi:10.1007/978-1-4939-7060-5_2.

Kharchenko MV, Aksyonov AA, Melikova MM, Kornilova ES. 2007. Epidermal growth factor (EGF) receptor endocytosis is accompanied by reorganization of microtubule system in HeLa cells. Cell Biol Int. 31(4):349-359. doi:10.1016/j.cellbi.2007.01.020.

Klein J, Bascands JL, Buffin-Meyer B, Schanstra P. 2016. Epidermal growth factor and kidney disease: a longlasting story. Kidney Int. 89(5):985-987. doi:10.1016/ j.kint.2016.02.020.

Lohman GJS, Zhang Y, Zhelkovsky AM, Cantor EJ, Evans TC. 2013. Efficient DNA ligation in DNARNA hybrid helices by Chlorella virus DNA ligase. Nucleic Acids Res. 42(3):1831-1844. doi:10.1093/ nar/gkt1032.

Lorenz TC. 2012. Polymerase chain reaction: basic protocol plus troubleshooting and optimization strategies. J Vis Exp. (63):e3998. doi:10.3791/3998.

Moore LD, Le T, Fan G. 2013. DNA methylation and its basic function. Neuropsychopharmalocology. 38(1):23-28. doi:10.1038/npp.2012.112.

Nair RR, Warner BB, Warner BW. 2008. Role of epidermal growth factor and other growth factors in the prevention of necrotizing enterocolitis. Semin Perinatol. 32(2):107-113. doi:10.1053/j.semperi.2008.01.007.

Nurmalasari. 2010. Konstruksi gen sintetik EGFsyn pengkode human epidermal growth factor (hEGF) menggunakan metode thermodinamically balanced insite-out (TBIO) [bachelor thesis]. [Depok]: Universitas Indonesia.

Osakabe K, Osakabe Y, Toki S. 2010. Site-directed mutagenesis in Arabidopsis using custom-designed zinc finger nucleases. Proc Natl Acad Sci USA. 107(26):12034-12039. 10.1073/pnas.1000234107.

Pikuła M, Langa P, Kosikowski P. 2015. Stem cells and growth factors in wound healing. Postępy Hig Med Dosw. 69:874-885. doi:10.5604/17322693.1162989.

Putri DED, Sriwidodo. 2016. Peranan epidermal growth factor pada penyembuhan luka pasien ulkus diabetes [The role of epidermal growth factor in wound healing of diabetic ulcer patients]. Farmaka. 14(4):61-69. doi: 10.24198/jf.v14i4.9531.g5071.

Rabhi I, Guedel N, Chouk I, Zerria K, Barbouche MR, Delagi K, Fathallah DM. 2004. A novel simple and rapid PCR-based site-directed mutagenesis method. Mol Biotechnol. 26(1):27-34. doi:10.1385/MB:26:1:27.

Rahimzadeh M, Sadeghizadeh M, Najafi F, Arab S, Mobasheri H. 2016. Impact of heat shock step on bacterial transformation efficiency. Mol Biol Res Commun. 5(4):257-261. doi:10.22099/MBRC.2016.3915.

Roux KH. 1995. Optimization and troubleshooting in PCR. Genome Res. 4(5):185-194. doi:10.1101/gr.4. 5.S185.

Savage CR, Hash JH, Cohen S. 1973. Epidermal growth factor: location of disulfide bonds. J Biol Chem. 248(22):7669-7672.

Savage CR, Inagami T, Stanley C. 1972. The primary structure of epidermal growth factor. J Biol Chem. 247(23):7612-7621.

She W, Ni J, Shui K, Wang F, He R, Xue J, Reetz M, Li A, Ma L. 2018. Rapid and error-free site-directed mutagenesis by a PCR-free in vitro CRISPR/Cas9-mediated mutagenic system. ACS Synth Biol. 7(9):2236-2244. doi:10.1021/acssynbio.8b00245.

Shivanand P, Noopur S. 2010. Recombinant DNA technology and genetic engineering: a safe and effective meaning for production valuable biologicals. Int $\mathrm{J}$ Pharm Sci Rev Res. 1(1):14-20.

Singh M, Yadav A, Ma X, Amoah E. 2010. Plasmid DNA transformation in Escherichia coli: effect of heat shock temperature, duration, and cold incubation 
of CaCl2 treated cells. IOSR J Biotechnol Biochem. 6(4):561-568.

Su Z, Huang Y, Zhou Q, Wu Z, Wu X, Zheng Q, Ding C, Li X. 2006. High-level expression and purification of human epidermal growth factor with sumo fusion in Escherichia coli. Protein Pept Lett. 13(8):785-792. doi:10.2174/092986606777841280.

Suortti T. 1997. Coupled size-exclusion chromatographyanion-exchange chromatography in the analysis of poly- and oligosaccharides. J Chromatogr A. 763(12):331-335. doi:10.1016/S0021-9673(96)00996-X.

Sánchez-Romero MA, Cota I, Casadesús J. 2015. DNA methylation in bacteria: from the methyl group to the methylome. Curr Opin Microbiol. 25:9-16. doi:10. 1016/j.mib.2015.03.004.

Tegel H, Ottosson J, Hober S. 2011. Enhancing the protein production levels in Escherichia coli with a strong promoter. FEBS J. 278(5):729-739. doi:10.1111/j. 1742-4658.2010.07991.x.

Vestheim H, Jarman SN. 2008. Blocking primers to enhance PCR amplification of rare sequences in mixed samples - a case study on prey DNA in Antarctic krill stomachs. Front Zool. 5(1):12. doi:10.1186/ 1742-9994-5-12.

Walquist MJ, El-Gewely MR. 2001. Mutagenesis: sitedirected. eLS:1-14. doi:10.1002/9780470015902. a0001000.pub4.

Wan H, Li Y, Fan Y, Meng F, Chen C, Zhou Q. 2012. A site-directed mutagenesis method particularly useful for creating otherwise difficult-to-make mutants and alanine scanning. Anal Biochem. 420(2):163-170. doi:10.1016/j.ab.2011.09.019.

Wu HG, Song SY, Kim YS, Oh YT, Lee CG, Keum KC, Ahn YC, Lee SW. 2009. Therapeutic effect of recombinant human epidermal growth factor (RhEGF) on mucositis in patients undergoing radiotherapy, with or without chemotherapy, for head and neck cancer: a double-blind placebo-controlled prospective phase 2 multi-institutional clinical trial. Cancer. 115(16):3699-3708. doi:10.1002/cncr.24414.

Xian CJ. 2007. Roles of epidermal growth factor family in the regulation of postnatal somatic growth. Endocr Rev. 28(3):284-296. doi:10.1210/er.2006-0049.

Xu Z, Colosimo A, Gruenert DC. 2003. Site-directed mutagenesis using the megaprimer method. New York: Humana Press. doi:10.1385/1-59259-409-3:203.

Zeng F, Harris RC. 2014. Epidermal growth factor, from gene organization to bedside. Seminars in Cell \& Developmental Biology. 28:2-11. doi:https://doi.org/10. 1016/j.semcdb.2014.01.011.

Zhang BZ, Zhang X, An XP, Ran DL, Zhou YS, Lu J, Tong YG. 2009. An easy-to-use site-directed mutagenesis method with a designed restriction site for convenient and reliable mutant screening. J Zhejiang Univ Sci B. 10(6):479-482. doi:10.1631/jzus.B0820367.

Zhu H, Qian J. 2012. Applications of functional protein microarrays in basic and clinical research. In: Friedmann T, Dunlap JC, Goodwin SF, editors. Advances in Genetics. Cambridge: Academic Press. p. 123-155. doi:10.1016/B978-0-12-394395-8.00004-9. 